\title{
INSTRUMENTOS ANTEMODERNOS DE MEDIAÇÃO DOS RISCOS: OPOSIÇÃO E CONTRIBUTOS DA IGREJA PARA O DESENVOLVIMENTO DAS PROTOFORMAS DOS SEGUROS
}

\author{
Manuel Menezes ${ }^{1}$
}

\begin{abstract}
RESUMO: Neste ensaio buscar-se-á desenvolver uma análise onde sejam explicitadas algumas das estratégias de que os seres humanos se foram socorrendo, desde tempos imemoriais, visando a proteger o seu património face às contingências, inseguranças advindas do espaço desconhecido. De entre as mesmas, iremos salientar alguns dos instrumentos mediadores dos «riscos» conexos com as atividades marítimas. Paralelamente tomar-se-á em consideração a forma como o discurso religioso conceptualizou esses instrumentos, com o intuito de mostrar as incompatibilidades que, durante séculos, existiram entre esse discurso e as práticas mercantis. Tomando por base as conexões estabelecidas com a dimensão dos riscos mediadores dessas mesmas práticas, o fundamento da usura será, então, trabalhado, com o intuito de mostrar que, apesar de, num primeiro momento, poder ser considerado como um elemento condicionador da implementação $e$ desenvolvimento de algumas das vias engendradas pelo ser humano visando a gestão do contingente, acabaria, em última análise, por se consubstanciar como um impulsionador da ação dos indivíduos na procura de novos meios de partilha de riscos que escapassem às sanções advindas dessa mesma usura.
\end{abstract}

Palavras-chave: Incerteza, Riscos, Direito Canónico, Usura, Seguros Marítimos.

ABSTRACT: In this paper we sought to develop an analysis where are explained some of the strategies that human beings used, since immemorial time, to protect their resources against the contingencies, insecurities resulting from unknown space. We will highlight some of the instruments mediators of "risks" associated with the maritime activities. We will also take into account how the religious discourse understood these instruments, with the intention to demonstrate the incompatibilities that, for centuries, existed between this discourse and experience. Based on the connections established

\footnotetext{
${ }^{1}$ Doutor em Ciências da Comunicação (especialidade de Comunicação e Cultura) pela Faculdade de Ciências Sociais e Humanas da Universidade Nova de Lisboa. Docente no ISMT e na UCP-CRB.
} 
between risks and experience, the argument of usury will be analyzed, with the intention to show that, although, in a first moment, it could be considered as an element that conditioned the implementation and development of some of the strategies engendered by human being with the intention of management the contingent, in the end it is transformed in a driving force behind the action of individuals in the search for new ways of sharing the risks that escaped the penalties resulting from this same usury.

Key-words: Uncertainty, Risks, Canon Law, Usury, Marine Insurance

\section{EMPRÉSTIMOS MARÍTIMOS}

Visando a proteger o seu património face às contingências, inseguranças advindas do espaço desconhecido, os seres humanos foramse socorrendo, desde tempos imemoriais, de várias estratégias com o fim último de transferir os «riscos» entre os distintos indivíduos. De entre os vários instrumentos antemodernos de mediação dos «riscos» conexos com as atividades marítimas gostaríamos, então, de sinalizar os empréstimos marítimos. Estes traduziam-se num acordo estabelecido entre o mercador ou o mestre do navio e um mutuante (ou dador-a-risco, segundo a aceção de Ferreira Borges, 1833), por intermédio do qual este emprestava uma determinada quantia visando o financiamento da viagem marítima (no caso do mercador), ou para a prossecução da viagem (quando estabelecido com o mestre num determinado porto em que o navio fazia escala). No caso de o navio chegar a bom porto, o mutuante receberia a quantia avançada acrescida de um interesse a uma taxa previamente estabelecida ${ }^{2}$ (denominada pelos romanos de periculi pretium), mas se, por qualquer um dos perigos enumerados, o navio e/ou as mercadorias se perdessem, a dívida estava saldada. O pagamento do empréstimo (no latim mutuum) ${ }^{3}$ acrescido do interesse ficava, então, condicionado ao sucesso do empreendimento marítimo e, caso o mesmo não lograsse êxito, transformava-se numa «indemnização» pelos danos ocorridos, não sendo o reembolso da dívida devido.

Os romanos denominavam esse empréstimo de foenus nauticum ${ }^{4}$; na língua francesa viria a ficar conhecido sob o nome de prèt à la grosse

\footnotetext{
${ }^{2}$ Esta aumentava em proporção à distância das viagens, chegando a atingir, durante a Idade Média, para as regiões mais longínquas uma taxa de 50\% (Gregory Kohn, 1999).

${ }^{3}$ De acordo com John T. Noonan (1995), a palavra provém da junção dos vocábulos meum e tuum - o meum tornou-se tuum.

${ }^{4}$ De acordo com Charles Molloy (1769) e Pierre B. Boucher (1803), era, também, denominado de usura marina.
} 
aventure $^{5}$ ou, somente, prèt à la grosse; os ingleses chamavam-lhe bottomry ${ }^{6}$, e no italiano prestito a cambio maríttimo ou bomeria que, em português, pode ser traduzido por bodemeria; utilizando-se, também, em inícios do século XIX, na nossa língua os termos «[...] contracto de risco, e dinheiro trajecticio, e ainda foenus náutico, como os Romanos» (Ferreira Borges, 1833: 63). Com as evoluções próprias dos costumes e das regulações que, subsequentemente, foram surgindo, este tipo de contrato apesar de alguns sobressaltos momentâneos, manter-se-ia como uma prática usual das atividades marítimas ao longo dos séculos seguintes. Referindo-se ao mesmo, Estienne Cleirac (1671), descreve-o como sendo uma prática muito habitual do seu tempo.

$\mathrm{O}$ empréstimo marítimo plasma uma das práticas mais antigas e usuais de transferência de riscos onde, buscando trocar um futuro incerto por um presente certo, o mercador/expedidor intentava transcorrer para $\mathrm{o}$ financiador os «riscos» a que o seu património iria estar sujeito ${ }^{7}$. Deverse-á assinalar que os «riscos» se consubstanciavam como um elemento fundamental do acordo, pois o contrato só era valido no caso de o barco e/ou as mercadorias ficarem sujeitos aos mesmos, estando, por conseguinte, a validade do contrato dependente dos eventos perigosos poderem ocorrer entre o decurso das datas - anteriormente estipuladas pelos contraentes - de início e fim da viagem ${ }^{8}$ : «faz parte da essência do contrat à la grosse, que o dinheiro seja empregue num objeto que seja

${ }^{5}$ Defendendo a existência deste tipo de contratos entre os atenienses, para Pierre B. Boucher a denominação francesa encontra justificação no facto de o financiador expor o seu dinheiro à «aventura do mar» causadora de muitos danos (1803: ix; 315; cf. Jean-Claude Colfavru, 1863).

${ }^{6}$ A proveniência do vocábulo inglês tem subjacente o entendimento que era feito do contrato. Isto é, como forma de segurança do pagamento do empréstimo o financiador ficava com a «hipoteca» do navio ou, mais precisamente, de partes específicas do mesmo: «um contrato de bodemeria, é um contrato onde o dono ou o mestre do navio contrai um empréstimo para financiar a sua viagem, empenhando a quilha ou o casco [bottom] do navio como segurança do pagamento» (Leone Levi, 1863: 794-795; cf. Estienne Cleirac, 1671; Charles Molloy, 1769; Ferreira Borges, 1833). Quando o empréstimo era feito sob determinadas mercadorias em específico, denominava-se respondentia (Ferreira Borges, 1833; Jean-Claude Colfavru, 1863).

${ }^{7}$ Do enunciado não se deve depreender que o mercador ficaria isento de qualquer risco. Ao subdividirmos os riscos, em riscos de navegação e de mercado, constata-se que, apesar dos primeiros, incluindo os perigos de mar, ficarem sob a alçada do financiador, os segundos, apreendidos como riscos comerciais, dado o estabelecimento de uma taxa prévia de interesse, correriam do lado do mercador. Sobre este aspecto, cf. Gregory Kohn (1999), González de Lara (2001).

${ }^{8}$ Quando estas não se encontravam explicitas no contrato, era norma considerar-se como riscos os eventos que poderiam ocorrer «desde o dia em que o navio fazia vela até ao dia em que ele ancorasse no porto do seu destino». 
exposto aos riscos de mar; e é necessário que, em caso de perda, o financiador justifique que ele tinha, por sua conta, os efeitos do dinheiro emprestado» (Pierre B. Boucher, 1803: 318; cf. Joseph Pothier, 1821: 398). Num outro discurso encontramos uma ideia similar, «se não tiver havido objetos expostos aos riscos de mar, como penhor do empréstimo, o contrato não será mais do que uma espécie de aposta e de jogo, sendo reprovado pela lei» (Jean-Claude Colfavru, 1863: 352) ${ }^{9}$.

Estas asserções são de extrema importância, na medida em que têm subjacente o elemento por intermédio do qual seria possível estabelecer a distinção - nem sempre clara - entre um ato que tinha por fim último uma aposta, um jogo e um contrato realizado com o intuito de proteger o património face aos eventos fortuitos. Isto é, o que permitia estabelecer a distinção entre os primeiros e os últimos era não só, mas também em primeiro lugar, o facto de a validade do contrato se encontrar dependente do elemento risco. Em segundo lugar, o modo como o «risco» era analisado, i.e., no caso da aposta/jogo a ação realizada atraía riscos desnecessários, enquanto, com a ação subjacente ao contrato, se pretendia minorar as possíveis consequências de riscos necessários.

Feito este pequeno introito, interessa-nos de seguida perceber como o discurso religioso conceptualizou estas questões. Tendo presente as incompatibilidades existentes, durante séculos, entre esse discurso e as práticas mercantis, buscar-se-á percecionar as razões subjacentes a essa rejeição por parte do direito canónico. Isto é, tomando por base as conexões estabelecidas com a dimensão dos riscos associados a essas práticas, o fundamento da usura será, então, trabalhado, com o intuito de demonstrar como o mesmo, apesar de, num primeiro momento, poder ser considerado como um elemento condicionador da implementação e desenvolvimento de algumas das vias engendradas pelo ser humano visando a gestão do contingente, acabou por se consubstanciar como um impulsionador da ação dos indivíduos na procura de novos meios de partilha de riscos que escapassem às sanções advindas dessa mesma usura.

\footnotetext{
${ }^{9}$ Sem particularizar a especificidade do perigo, no Compendio Moral Salmaticense defende-se a nulidade do contrato caso o perigo fosse fingido ou se um dos contraentes, apesar de saber da inexistência do mesmo, estabelecesse um determinado preço pelo perigo a correr; sobre este aspecto, vidé Marcos de Santa Teresa (1805: $592,594)$.
} 


\section{A PROIBIÇÃO DA PRÁTICA DA USURA}

Sustentando o seu ponto de vista no argumento da usura ${ }^{10}$, durante um lato período, tanto a lei canónica como a lei civil ${ }^{11}$, posicionaram-se contra os contratos estabelecidos entre os indivíduos visando a transferência de riscos. Assim sendo, gostaríamos de, num primeiro momento, intentar clarificar o porquê dessa mesma oposição, para, seguidamente, procurar demonstrar como o posicionamento da Igreja, por um lado, viria a ser abalado a partir do momento em que a dimensão do risco passou a ser aceite como elemento mediador dos contratos e, por outro lado, se viria a consubstanciar como um elemento de primordial importância para a emergência de novos instrumentos mediadores dos «riscos» ${ }^{12}$.

$\mathrm{O}$ posicionamento geral da igreja face à usura (ou, se preferirmos, em relação ao que era considerado como um lucro ilegal advindo de um empréstimo) e, por consequência, face ao usurário ${ }^{13}$, pautou-se por uma rejeição em crescendo ${ }^{14}$. Até ao século IX, embora desaprovando de um

10 O vocábulo provém do latim e, segundo o Direito Romano, significava o pagamento/lucro pelo uso de um empréstimo - «lucrum ex mutuo proveni ens» (Thomas Moser, 1997; Gary Coulter, 1999).

${ }^{11}$ Esta, de um modo geral, encontrava-se próxima da lei canónica no concernente à proibição da usura. Não obstante, durante o século XIV, muitas cidades italianas permitiram o exercício de empréstimo de dinheiro aos judeus, obtendo para tal o consentimento papal de modo a evitar a lei canónica (Gordon Griffiths et al, 1994). A partir do século XVI, indiciando uma reformulação do conceito de usura (apreendido já não como qualquer interesse recebido para além do emprestado, mas enquanto interesse exageradamente elevado), começa a ser permitida a cobrança do interesse a $5 \%$ (na Alemanha) e a $12 \%$ ao ano (em Inglaterra), sendo considerados usurários os contratos que definissem taxas superiores; em Portugal, os juros passaram a ser legais durante o século XVIII, mais precisamente por Alvará de 6 de Agosto de 1757; em França, no entanto, assumindo a fama de ser o país detentor das leis mais severas contra a usura, a proibição manter-se-ia até 1789 , ano em que, uma lei de 12 de Outubro, passou a admitir o interesse a uma taxa de 5\% (Ferreira Borges, 1833; Böhm-Bawerk, 1884; Louis Garriguet, 1907; Arthur Vermeersch, 1910; John Munro, 2003).

${ }^{12}$ Para uma leitura similar relativamente à segunda dimensão, cf. Giovanni Ceccarelli (2001).

${ }^{13}$ Para uma análise aprofundada das representações sociais negativas existentes sobre os usurários ao longo dos séculos XII e XIII, cf. Jacques le Goff (1986).

${ }^{14}$ Essa rejeição não se viria a consubstanciar, no entanto, como algo de impeditivo à instituição da usura enquanto prática corrente, dada a existência de um hiato significativo entre o que as leis determinavam e o praticado pelos indivíduos. A própria multiplicação de proibições, essencialmente, eclesiásticas, mas também civis, pode ser apreendida como um sinal clarividente da sua manutenção enquanto prática generalizada. 
modo genérico, sob o argumento de o dinheiro emprestado não se reproduzir $^{15}$, a Igreja condenava esta prática, essencialmente, se ela fosse praticada por clérigos (Böhm-Bawerk, 1884; Dickson White, 1898; Arthur Vermeersch 1910; Gary Coulter, 1999) ${ }^{16}$. Esta proibição, em específico, surge logo no I Concílio Ecuménico da Igreja (Concílio de Niceia - 325 d.C.), onde, no cânon 17, é visível a condenação dos clérigos que, por cobiça ou luxúria, emprestassem dinheiro por interesse, defendendo-se, igualmente, a expulsão do clero ${ }^{17}$ para todos os que fossem apanhados em tais práticas. Mas, a interdição rigorosa a todo e qualquer cristão, só ocorre no direito canónico ao longo da Idade Média, sendo as obras de Marcos de Santa Teresa $(1805)^{18}$ e, especialmente, a de Enrique Denzinger $(1963)^{19}$ férteis em exemplos quanto à manutenção deste posicionamento entre os séculos XII e XVIII. Assim, sob a égide do Papa Inocêncio II (1130-1143), o II Concílio de Latrão, ocorrido em 1139:

\footnotetext{
${ }^{15} \mathrm{O}$ discurso religioso foi buscar este argumento aos clássicos. O mesmo encontravase já presente na maioria dos escritores gregos e romanos que, partindo de uma apreensão do dinheiro como sendo algo estéril, improdutivo, olhavam o interesse com desconfiança e/ou repúdio, porquanto a tentativa de a partir de algo estéril tentar fazer emergir algo produtivo era, em si, contraditória, visto «pecunia non parit pecuniam», sendo deste modo considerado contra natura segundo a aceção de Aristóteles (BöhmBawerk, 1884; Dickson White, 1898; Arthur Vermeersch, 1910; Jacques le Goff, 1986; John T. Noonan, 1995; Gary Coulter, 1999; Muñoz de Juana, 2001; John Munro, 2003).

${ }^{16}$ Jacques le Goff (1986) indica uma data distinta para o alargamento da proibição aos leigos, afirmando ter a mesma ocorrido no Concílio de Clichy datado de inícios do século VII.

${ }^{17}$ Sobre este aspecto, cf. The First Council of Nicaea (1900).

${ }^{18}$ Esta obra toma como suporte o trabalho, editado em 1779, de António de San Joseph (1716-1794), denominado Compendium Salmanticense Universae Theologiae Moralis, resumo de um curso moral levado a cabo pelo Colégio Carmelita de San Elias de Salamanca. O mesmo viria a ser alvo de várias edições em Itália e em Espanha, sendo que o Compêndio de Marcos de Santa Teresa se apoia na edição espanhola de 1791.

19 Teólogo alemão do século XIX (1810-1883), de seu nome Heinrich Joseph Dominicus Denzinger. Editou em 1854 o Enchiridion Symbolorum et Definitionum, um manual onde estão coligidos os principais decretos dos sínodos, as definições dos concílios e as encíclicas do magistério eclesiástico, entre outros documentos eclesiásticos que ao longo da história foram surgindo na esfera pública. Esta obra tem vindo a sofrer reedições sucessivas com a inclusão de novos documentos. A versão por nós consultada tem por base a 31. ${ }^{\mathrm{a}}$ edição.
} 
(i) condenava - no cânone 13 - a ganância insaciável dos prestamistas por ela ser contra as leis humanas e divinas do Antigo e do Novo Testamento ${ }^{20}$;

(ii) privava os usurários falecidos, sem sinal de arrependimento, da sepultura eclesiástica;

(iii) proibia os membros do clero de receber os mesmos (Enrique Denzinger, 1963: D-365) ${ }^{21}$.

O Papa Alexandre III (1159-1181), na Carta In Civitat Tua ao arcebispo de Génova, viria a reafirmar a usura como pecado e, a par com uma intensificação dos discursos contra a usura ao longo do século XIII (Louis Garriguet, 1907; Jacques le Goff, 1986; John Munro 2003) ${ }^{22}$, no

${ }^{20} \mathrm{O}$ Antigo Testamento é referido frequentemente como fonte de sustentação para uma leitura da usura, enquanto prática moralmente questionável. O Deuteronómio (23: 20), por exemplo, explicita a proibição dos empréstimos com juros entre judeus, proibição essa que, no entanto, não se estendia aos «contratos» celebrados entre um judeu e um «estrangeiro»: «não exigirás juros ao teu irmão, quer se trate de dinheiro, quer se trate de géneros alimentícios, ou de qualquer outro género. Poderás emprestar com juros ao estrangeiro mas não ao teu irmão, se queres que o Senhor, teu Deus, abençoe todos os teus trabalhos na terra em que vais entrar para a possuir». Proibições similares encontram-se, igualmente, em outros livros do Pentateuco; sobre este aspeto, cf. Êxodo, 22: 25, Levitico, 25: 36-37. Thomas Moser (1997), na análise aprofundada que faz sobre a presença de leis no Antigo Testamento que indiciassem a proibição da usura, refere ter sido por influência do Deuteronómio que a proibição viria a surgir nos Livros que o precederam. Segundo a sua aceção, inicialmente esta proibição não se encontraria ínsita no Exxodo e no Levitico vindo, posteriormente, a ser acrescentada para se encontrar de acordo com a proibição que viria a ser incluída pela primeira vez, por volta do século VII a.C., no Deuteronómio. Quanto ao recurso ao Novo Testamento, podemos dar como exemplo a Carta Consuluit Nos, carta essa, escrita pelo Papa Urbano III (1185-1187) a um presbítero de Brescia. Ao ser questionado sobre se alguns negócios deveriam ser considerados usura, responde que a lei proibia os mesmos, nomeadamente o Evangelho segundo São Lucas (6-35), onde se pode ler «emprestai sem nada esperar em troca» (Enrique Denzinger, 1963: D-403). O recurso a este mesmo evangelho aparece, também, no contexto da justificação da existência da usura mental, ou seja, o esperar um benefício de um empréstimo, independentemente das razões subjacentes ao mesmo, fazia do indivíduo um usurário; sobre este aspeto, vide Marcos de Santa Teresa 1805: 586; John Noonan, 1995; Gary Coulter, 1999).

${ }^{21}$ Para a análise de outras penas (a serem aplicadas tanto no espaço do visível como do invisível) a que se sujeitavam os usurários, vide, para o século XIV (Gordon Griffiths et all, 1994) e para o século XVII (Marcos de Santa Teresa, 1805: 597).

22 Durante o século XIII, o fortalecimento das críticas do discurso religioso face à usura, pode ser apreendido como tendo sido a via encontrada pela Igreja para lutar contra o progresso económico e comercial que ameaçava o poder até aí detido. Para uma análise dos argumentos esgrimidos durante este período pelo discurso religioso (podendo-se salientar de entre os mesmos os de São Tomás de Aquino), 
Concílio de Vienne (1311-1312), chega-se ao ponto de declarar como herético todo aquele que intentasse afirmar o contrário - «se alguém cair no erro de pretender afirmar pertinazmente que o exercício das usuras não é pecado, decretamos que seja castigado como herege» (Enrique Denzinger, 1963: D-394; D-479; Marcos de Santa Teresa, 1805: 585).

No século XVII, o Papa Inocêncio XI (1676-1689), reafirmou a reprovação da usura, ao condenar uma proposição segundo a qual seria lícito ao que emprestava dinheiro exigir algo mais do que o capital, com a base na argumentação de o dinheiro que se possuía valer mais do que aquele que se poderia vir a receber (Enrique Denzinger, 1963: D-1191). Mais recentemente, seguindo na senda destes discursos, o Papa Bento XIV (1740-1758) ao abordar, na famosa Encíclica Vix Pervenit de 1745, o tema da «usura e outros lucros desonestos» condena-a com base nos argumentos de a mesma, para além de ser contra as leis divinas e humanas, ser contrária à natureza do próprio contrato - «aquele tipo de pecado que se chama usura, e tem o seu próprio assento e lugar no contrato de empréstimo, o qual por sua própria natureza só pede que seja devolvida a mesma quantidade que se recebeu ${ }^{23}$, se quer que seja devolvido mais do que o que se recebeu, e pretende, portanto, que, por razão do próprio empréstimo, se deve algum lucro mais além do capital. Por isso, todo o lucro semelhante que supere o capital é ilícito e usurário» (Enrique Denzinger, 1963: D-1475, sublinhado nosso).

\section{EXCEÇÕES À LEI: O LUCRO HONESTO}

Os discursos até agora campeados, embora transubstanciando a gratuitidade do empréstimo num dogma, não permitem, no entanto, a afirmação taxativa de que todos os emolumentos diretamente advindos do capital - interesse lucrativo - seriam rigorosamente proibidos pela Igreja. Isto é, a análise dos discursos por nós encetada admite, embora nem sempre de um modo claro, por um lado, uma leitura onde são visíveis algumas exceções à lei e onde, por consequência, o «lucro» era considerado honesto. Por outro lado, pensamos ser correta a asserção, de que as exceções enunciadas se consubstanciam como o resultado, (i) de

nomeadamente quanto à rejeição da usura com base na lei natural (o dinheiro enquanto algo estéril e fungível, transferência de propriedade e apreçamento do tempo), vide Böhm-Bawerk (1884: I.I.22-26); Louis Garriguet (1907: 28).

${ }^{23}$ De acordo com a aceção de Muñoz de Juana, «a reprovação moral associada às práticas usurárias, residia na dificuldade em justificar - com base na justiça comutativa - um pagamento maior do que o capital inicialmente desembolsado e que era, somente, compensado pelo decurso do tempo» (2001: 34; cf. Gary Coulter, 1999; John Munro, 2003). 
cedências progressivas, por parte do direito canónico, às pressões advindas do desenvolvimento comercial - «revolução comercial» segundo alguns - decorrente do crescimento económico ${ }^{24}$; (ii) de uma inflexão, de um novo viés, na abordagem da temática da usura, ou seja, estas exceções só se tornaram possíveis a partir do momento em que o cerne da análise foi trasladado do empréstimo em si para as circunstâncias concretas em que o mesmo ocorria. Por outras palavras, a análise ao se deslocar do empréstimo em abstrato para as condições reais mediadoras do mesmo, propugnou o aparecimento das condições necessárias à aceitação das exceções à lei ${ }^{25}$.

Uma ressalva conectava-se com o que podemos denominar de incerteza futura, i.e., um contrato não seria considerado usurário (não obstante estipular que as mercadorias, valendo nesse instante $X$, seriam pagas a um preço de $\mathrm{Y}$ aquando do momento de saldar a dívida), quando fosse justificado com base no argumento de o vendedor no momento em que a transação foi realizada não ter a certeza de quanto as mercadorias valeriam no momento determinado para o pagamento das mesmas «venditio sub dubio». A aceitação deste tipo de contrato tinha subjacente, pensamos, a boa-fé dos contraentes, porquanto, dado desconhecerem realmente o preço futuro, consideravam ser o preço $\mathrm{Y}$ aquele que seria justo estipular. Desta opinião era o Papa Alexandre III, visto na missiva por nós enunciada supra, referir: «dizes que, na tua cidade sucede com frequência, alguns prometem, ao comprarem pimenta e canela ou outras mercadorias que então não valem mais de cinco libras, que no termo convencionado pagarão seis libras. Assim, ainda que este contrato não possa ser considerado por tal forma como usura, os vendedores incorrem no entanto em pecado, a não ser que seja duvidoso se aquelas mercadorias, no momento do pagamento, valerão mais ou menos» (Enrique Denzinger, 1963: D-394). Um outro exemplo é-nos fornecido pelo Papa Gregório IX (1227-1241), dado, na sequência de uma situação similar, assinalar: «[...] como razoavelmente se duvida se [as mercadorias - MM] valerão mais ou menos no momento do pagamento, não deve [o

\footnotetext{
24 A importância das interconexões existentes entre as dimensões religiosa e económica são tematizadas por Jacques le Goff ao assinalar que «a Igreja, os teólogos, os canonistas e, não o esqueçamos, os pregadores e confessores da Idade Média ao tratarem questões religiosas, o pecado da usura neste caso, mostram o impacto da religião em fenómenos que hoje chamamos de "económicos"》 (1986: 101).

${ }^{25}$ Num outro contexto, para uma análise das inflexões ocorridas ao longo do século $\mathrm{XV}$, por razões políticas e económicas, na política papal a favor e/ou contra os judeus e, por conseguinte, favorecendo a usura ou rejeitando-a, cf. Gordon Griffiths et al (1994).
} 
contrato - MM] por isso ser denominado de usurário» (Enrique Denzinger, 1963: D-448).

Outra situação onde eram admitidas exceções, enquadrava o que pode ser entendido como a razoabilidade dos ganhos. Explicitando, de acordo com alguns argumentos, os contratos não deveriam ser considerados usurários (i) se os interesses advindos dos mesmos não fossem muito elevados, (ii) se os mesmos não ultrapassassem significativamente um valor considerado sensato ou (iii) nos casos em que a condição socioeconómica do devedor fosse boa, bem como (iv) quando eram apreendidos como sendo um rendimento necessário à satisfação das necessidades do indivíduo. Deve-se, no entanto, salientar que, nesta dimensão encontrámos, tanto, discursos que comungam do raciocínio supra, como outros que se lhe opõe. Exemplos do primeiro tipo são os do:

(i) Sumo Pontífice Leão X (1513-1521) para quem, na Bula Inter Multíplices de 1515, o interesse moderado praticado pelos Montes de Piedade, não deveria ser considerado usurário (antes pelo contrário, deveria ser entendido como uma ação meritória), porquanto o interesse era pedido, não em virtude o empréstimo, mas, para fazer face aos gastos inerentes à manutenção dos mesmos (Enrique Denzinger, 1963: D-73; Marcos de Santa Teresa, 1805: 598 $)^{26}$;

(ii) Teólogo espanhol Martin de Azpilcuelta (1492-1586) que, nos seus ensinamentos morais, advogava ser aceitável um lucro moderado quando o mesmo fosse definido como sendo o salário daquele que fizesse do negócio honesto a sua atividade principal (Muñoz de Juana, 2001).

Por sua vez, os discursos onde este tipo de argumento era recusado, justificavam o seu ponto de vista com base na alegação de todo e qualquer tipo de usura ser proibida tanto pela natureza do contrato em si, como pelas leis divinas, humanas e naturais. Seguindo esta lógica, o Compendio Moral Salmaticense considerava o raciocínio do primeiro tipo

\footnotetext{
${ }^{26}$ Em nossa opinião, esta exceção à lei teve por base razões humanitárias, visto o fim último da instituição dos Montes de Piedade ter sido o de ajudar os pobres em necessidade. Emprestando-lhes dinheiro a taxas moderadas visava, em última instância, livrá-los das elevadíssimas taxas praticadas pelos mutuantes em geral. Função essa, ainda presente e, até certo ponto, não totalmente concretizada, em meados do século XIX, «os montes de piedade têm, essencialmente, por fim retirar aqueles que não possuem dinheiro, da tirania da usura; mas, eles não deveriam exagerar o interesse que eles exigem, sob pena de imitar o mal que eles querem evitar» (Armand de Melun, 1849: 43; cf. Adolphe Coste, 1882).
} 
um erro ímpio. Criticando a doutrina professada por João Calvino (1509$1564)^{27}$, não aceitava a justificação da condição socioeconómica do devedor - «Calvino juntando-se aos gregos cismáticos, quer que seja lícito exigir aos ricos um lucro moderado pelo empréstimo; mas isto é um erro ímpio», devendo, por conseguinte, a usura ser rejeitada independentemente do argumento utilizado - «toda a usura encontra-se geralmente reprovada, sem exceção de pessoas, como o sentem todos os católicos, contra os hereges; e, assim, é sempre ilícita por mais moderado que seja o ganho, moderado ou poderoso aquele a quem se exige» (Marcos de Santa Teresa, 1805: 585, 587) ${ }^{28}$. O Papa Bento XIV, na encíclica já referida, viria a reafirmar e a confirmar o posicionamento da Igreja quanto a esta questão; sustentando a sua tese na natureza do contrato de empréstimo, o perdão da usura com base nos argumentos anteriormente mencionados era rejeitado ${ }^{29}$.

Este discurso, no entanto, manifesta, em nossa aceção, um posicionamento dúbio ou, quiçá, estratégico, na medida em que uma leitura atenta do $\$ 3$ n. ${ }^{\circ} 3$ da encíclica de Bento XIV, deixa em aberto a possibilidade de outro tipo de contratos não serem considerados usurários, designadamente os contratos em que o interesse é concebido como salário o que, a ser assim, vai de encontro aos argumentos esgrimidos pelos discursos do primeiro tipo: «com estas observações, no entanto, nós não negamos que, em simultâneo, com o contrato de empréstimo existam certos títulos, que não são em absoluto inatos e intrínsecos à própria natureza do empréstimo em geral. Destes outros títulos, advêm razões inteiramente justas para exigir algo mais além do capital devido pelo empréstimo. Nem é negado que é frequentemente possível, por meio de outros contratos de natureza totalmente distinta do

${ }^{27}$ Consubstanciando-se como defensor do sucesso material pela via do trabalho, do enriquecimento, em sua opinião as leis divinas não evidenciavam uma rejeição liminar da usura, devendo, por isso, ser abertas algumas exceções. Para uma análise do argumento calviniano contra a esterilidade do dinheiro, cf. Böhm-Bawerk (1884: I.II.15-18).

${ }^{28}$ No século XVII, em resposta à tese de que por usura se deveria entender somente «interesse opressivo», a Faculdade de Teologia da Sorbonne reafirmou ser qualquer interesse usurário não importando quão pequeno fosse (Dickson White, 1898: 277).

${ }^{29}$ No $\$ 3$ n. ${ }^{\circ}$ da Encíclica Vix Pervenit, pode ler-se: «nós não podemos perdoar o pecado da usura, argumentando que o ganho não é grande ou excessivo, mas, antes, moderado ou pequeno; nem pode ser perdoada, argumentando que aquele a quem se empresta é rico; nem mesmo argumentando que o dinheiro emprestado não ficou ocioso, mas que é aplicado de forma útil, para aumentar a sua fortuna, na compra de novas propriedades, ou na realização de negócios lucrativos. A lei que regula os empréstimos consiste necessariamente, na igualdade do que é dado e devolvido; uma vez a igualdade estabelecida, todo aquele que exigir mais do que isso, viola os termos do empréstimo» (Enrique Denzinger, 1963: D-1476). 
empréstimo, gastar e investir justamente o seu dinheiro para se prover a si próprio com rendimento anual ou, também, para exercer o comércio e o negócio lícito» (Enrique Denzinger, 1963: D-1477).

Tomando em atenção a possibilidade de existência de outros títulos sancionados pela encíclica, podemos sinalizar o dano emergente e o lucro cessante que, segundo a acepção de Jacques le Goff (1986), podem ser inseridos no quadro de uma indemnização. $O$ primeiro previa a possibilidade de o mutuante receber um interesse devido às percas que o mesmo pudesse sofrer pelo facto de ter emprestado o dinheiro; quanto ao segundo, o interesse era aceite como legítimo dado o indivíduo a partir do momento em que emprestava o dinheiro renunciar a potenciais ganhos que, possivelmente, poderia obter no futuro por intermédio do investimento do dinheiro emprestado.

Estes títulos são referidos no Compendio Moral Salmaticense onde, se chamava à atenção para os cuidados a ter com os mesmos, visando a aferição da sua real proveniência, i.e., dado muitas vezes serem utilizados como um subterfúgio para esconder a usura, só seriam aceites se, de facto, fossem provenientes do empréstimo - «contudo se, verdadeiramente, se encontrarem no empréstimo e tiverem a sua origem nele, é parecer comum, ser lícito exigir algo ultra sortem pelos mesmos; porque, tanto um como o outro são extrínsecos ao empréstimo e preço estimável. Existe, no entanto, uma diferença entre o lucro cessante e o dano emergente, enquanto este se pode exigir totalmente, aquele não, só quando se estime a esperança de o conseguir e tendo presente o perigo e as despesas necessárias à sua prossecução» (Marcos de Santa Teresa, 1805: 590).

Por fim, gostaríamos de referir os casos em que, por circunstâncias excepcionais, se provasse que os mesmos eram o resultado de um interesse compensatório ${ }^{30}$, podendo-se aqui, salientar duas dimensões.

Por um lado, encontrámos uma situação onde o contrato não era considerado usurário com base no argumento de o interesse ter subjacente um agradecimento. A argumentação desenvolvida, no Compendio Moral Salmaticense caminhava neste sentido - «[...] ou o que recebeu o empréstimo deu o excesso gratamente, ou não. No primeiro, o mutuante poderá retê-lo, conhecendo a vontade do dador. No segundo estará

\footnotetext{
${ }^{30}$ Segundo a aceção de Louis Garriguet (1859-1927), distinguindo-os dos interesses lucrativos, os mesmos deveriam ser apreendidos como sendo aqueles que «[...] no mutuum não emergem como recompensa do empréstimo, mas como indemnização do dano que promovem ou do perigo de perca ao qual se expõe aquele que empresta. Enquanto os interesses lucrativos se baseiam no próprio empréstimo, os interesses compensatórios, repousam em circunstâncias, em considerações extrínsecas ao empréstimo, em títulos conexos com o empréstimo de forma acidental» (1907: 32).
} 
obrigado a restituir o excesso, como injustamente adquirido» (Marcos de Santa Teresa, 1805: 586). No entanto, apesar de ser lícito ao mutuante esperar receber algum lucro em sinal de agradecimento, não poderia expressar essa intenção a quem emprestava o dinheiro. Será neste contexto que deve ser entendida a condenação que, em 1679, o Papa Inocêncio XI (1676-1689) fez da seguinte proposição - «não é usura exigir algo além do capital como devido por benevolência e gratidão; mas, só, se exige como devido por justiça» (Enrique Denzinger, 1963: D1192).

Por outro lado, o quadro das exceções à usura enquadra, igualmente, uma outra argumentação que, para nós, se reveste de um interesse particular, nomeadamente a que subentendia o lucro advindo do empréstimo como sendo uma recompensa pelos perigos corridos «periculum sortis». Não descurando as razões já avançadas, pensamos ser, igualmente, adequado, incluir no raciocínio presente (da valorização do elemento do perigo), o quadro subjacente à incerteza futura, na medida em que, para a aceitação desse tipo de contratos, pode ser acrescentada uma outra justificação, designadamente a que remete para a aceitação dos mesmos com base no facto de o vendedor ao estipular um determinado preço no momento da transação se expor ao perigo de ganhar ou perder dinheiro (Marcos de Santa Teresa, 1805: 581).

Deve-se, no entanto, salientar que, o argumento do perigo corrido, nem sempre foi aceite como válido, sendo exemplo disso o posicionamento de Gregório IX. Em 1234, este Sumo Pontífice no Decreto «Naviganti vel uenti ad nudinas» proíbe os empréstimos marítimos com base no argumento da usura e, numa Carta ao Irmão R., postula de um modo claro a rejeição da tese do perigo, argumentando: «o que empresta a um navegante ou a alguém que vai à feira, certa quantidade de dinheiro, por se expor ao perigo, se recebe algo mais do capital, [não?] deve ser tido por usurário» (Enrique Denzinger, 1963: D$448) »^{31}$. Não obstante, num primeiro momento poder ser apreendida

\footnotetext{
${ }^{31}$ Um outro exemplo é-nos apresentado por Muñoz de Juana (2001). Na análise desenvolvida sobre os ensinamentos morais de Martin de Azpilcueta, afirma que o mesmo rejeitava a compensação que buscava a justificação no perigo, com base no entendimento de os perigos serem corridos pelos mercadores a quem era emprestado o dinheiro e não por aquele que procedia ao empréstimo. Embora com uma argumentação distinta (mais próxima da proibição conexa com a impossibilidade de o tempo ser vendido), um outro exemplo da oposição aos seguros encontramo-lo em Frei João Sobrinho, um religioso carmelita português. Escrevendo em finais do século XV, no seu Tratado de Justiça Comutativa (1494), justificava o seu ponto de vista em duas ordens de razão: em primeiro lugar, porque, o segurador procurava vender algo que não era pertença sua, pois, a segurança de um empreendimento encontrava-se única e exclusivamente dependente da vontade divina; em segundo lugar, visto o
} 
como um condicionalismo, a proibição emanada deste decreto vir-se-ia a revelar importante, tanto ao nível da influência positiva exercida na busca de novas estratégias para a partilha de riscos, como, também, pelo facto de a mesma ter dado origem a um profundo debate, entre os teólogos e os canonistas, sobre a importância que deveria ser adstrita ao risco nos contratos estabelecidos pelos mercadores (Giovanni Ceccarelli, 2001). Debate esse que, em nossa aceção, conduziria a uma aceitabilidade em crescendo do elemento risco como sendo um justificativo suficiente para a exoneração dos contratos face à usura ${ }^{32}$.

\section{PERICULUM SORTIS: ARGUMENTO A FAVOR DO PREÇO PELOS RISCOS CORRIDOS}

Enquadrando, num primeiro momento, os perigos conexos com as possibilidades de atraso nas datas estipuladas e/ou não pagamento por parte do devedor, os argumentos vir-se-iam a direcionar gradualmente para a aceitação de outros perigos associados às viagens por terra e por mar.

De um modo geral, entre os séculos XVI e XVII, um interesse proporcional aos «riscos» corridos passa a ser aceite como legal pela maioria dos autores consagrados e os próprios teólogos foram gradualmente levados a aceitar o traço redentor presente no risco (Arthur Vermeersch, 1910; Lorraine Daston, 1988; John Noonan, 1995). De acordo com a opinião de Gerd Gigerenzer et all (1989), Gary Coulter (1999), este argumento viria a ser aceite em 1645 pela Sagrada Congregação da Propaganda. No entanto, nós encontrámos uma outra fonte que indicia uma aceitação mais remota, remetendo nomeadamente para ano de 1515 quando, no V Concílio de Latrão, se afirma que havia «[...] usura quando houvesse ganho que não proviesse de uma causa frutífera, e que não implicasse nem trabalho, nem despesa, nem risco da parte do emprestador» (apud Louis Garriguet, 1907: 12, sublinhado nosso). No caso concreto português, segundo a aceção de Ferreira Borges (1833), o contrato de risco foi sendo sucessivamente proibido ao longo do século XVII e, em meados do século XVIII, continuava a ser

contrato de seguro ao encontrar a sua sustentação em algo impossível de ser conhecido, consubstanciava-se como uma ofensa ante as prerrogativas de Deus, não sendo, por isso, mais do que uma arte divinatória (Giovanni Ceccarelli, 2001).

${ }^{32} \mathrm{Um}$ dos primeiros sinais da mudança surge logo em meados do século XIII por intermédio do grupo franciscano da Universidade de Paris que passou a advogar dever o «[...] periculum, em paralelo com o trabalho, a escassez e a habilidade profissional, ser considerado um aspeto básico da justificação moral do lucro comercial» (Giovanni Ceccaralli, 2001: 614). 
rejeitado sob o pretexto da usura, vindo só a ser legalizado por alvará de 5 de Maio de 1810.

Quanto ao caso concreto da navegação, constata-se, como já salientámos, que o financiador ao se responsabilizar pelos perigos da viagem, colocava em risco o seu dinheiro durante o período em que decorria o empréstimo, porquanto caso a viagem não fosse bem sucedida poderia perder todo o dinheiro investido, logo, deveria receber uma compensação. Destarte, as razões avançadas para a não inclusão destes contratos no contextos dos contratos usurários prendia-se, então, com o facto de o perigo ser visto como elemento estranho à natureza do contrato, ou seja, o perigo de o dinheiro emprestado ser perdido passou a ser considerado como um perigo exterior ao contrato em si, na medida em que poderia ocorrer de modo acidental e independentemente do contrato:

- «pode-se receber alguma coisa ultra sortem pelo dito perigo extrínseco, se verdadeiramente o houver, aferindo-se a quantidade com juízo prudente, de acordo com o risco, e a condição que háde satisfazer, porque expor-se ao perigo de perder o emprestado, ou de não o poder cobrar sem dispêndio próprio, é coisa estranha ao empréstimo, e preço apreciável e, assim, não se pede o excesso pelo empréstimo, mas por uma coisa que em relação a ele é, de todo, acidental» (Marcos de Santa Teresa, 1805: 591-592) ${ }^{33}$.

Por outras palavras, o ganho daquele que emprestava advinha não do empréstimo em si, mas dos perigos por ele corridos ao longo do período em que o dinheiro foi emprestado. Logo, o que distinguia este tipo de contratos dos usurários era o perigo corrido (ou não) pelo mutuante, ou seja, todo e qualquer contrato que produzisse lucro sem que o elemento perigo corresse do lado do mutuante era considerado usurário $-\ll[\ldots]$ Dinheiro emprestado a Interesse é entregue ao Perigo do que recebe o empréstimo e o Lucro do mesmo é meramente o Preço de um simples Empréstimo e é denominado Usura. Mas, o Lucro do outro [pecunia trajectitia] é uma Recompensa pelo Perigo e Aventura de Mar, de que o mutuante se encarrega durante o Empréstimo, que deve ser entendido até que a Viagem termine» (Charles Molloy, 1769: 128; cf. 136; cf. Joseph Pothier, 1821: 390) $)^{34}$.

\footnotetext{
${ }^{33}$ Dickson White (1898), dá-nos conta de um argumento similar defendido, no século XVIII, pelo Doutor da Igreja Alfonso de Liguori.

${ }^{34}$ Giovanni Ceccarelli (2001) dá-nos conta de um outro argumento surgido ao longo do século XVI a favor dos seguros, podendo-se destacar de entre os defensores do mesmo o frade dominicano espanhol Domingo de Soto (1494-1560). Deslocando a análise dos contraentes em si, para a sociedade como um todo, a razão de ser do
} 
Dito isto, interessa acrescentar que, em nossa aceção, a nãoaceitação de contratos vários com base no argumento da usura, se consubstanciou como um elemento impulsionador do aparecimento de novos instrumentos de mediação dos «riscos». Quer dizer, tendo presente, por exemplo, as proibições emanadas, em 1234, do Decreto Naviganti de Gregório IX, advogamos terem as mesmas conduzido os mercadores à procura de novos meios de partilha de riscos que escapassem às sanções legais decorrentes da usura. O referido poder-se-á consubstanciar como justificação da importância crescente que, a partir do século XII, adquiriram instrumentos tais como os Contratos de Commenda, as Letras de Cambio e os Seguros Marítimos.

\section{À GUISA DE CONCLUSÃO}

Os empréstimos marítimos também eram conhecidos sob o nome de usura marina o que, de per si, indicia imediatamente o olhar negativo e a, consequente, rejeição manifesta pelo discurso religioso ante este instrumento mediador dos riscos. A justificação para este posicionamento, como tivemos oportunidade de demonstrar, encontravase no facto de a responsabilização pelos riscos implicar o pagamento de um interesse que, de acordo com a argumentação adstrita à usura, era considerado ilegal sob a ótica do direito canónico, porquanto, de acordo com a lei natural, encontrando-se a «esterilidade» e a «fungibilidade» entre as suas características, o dinheiro não se podia reproduzir ou, mais precisamente, o dinheiro emprestado não se reproduzia. Face a esta argumentação, todo $\mathrm{o}$ interesse recebido além do inicialmente despendido, era considerado como o resultado de uma prática moralmente questionável, um pecado, dado se encontrar em contradição com as leis humanas e divinas. A este razoamento acrescia ainda o facto de uma análise mais circunspecta demonstrar ser o interesse contrário à própria natureza do contrato de empréstimo, pois, esta só exigia a devolução de uma quantidade igual à anteriormente recebida.

Em consequência de pressões várias, a argumentação reveladora da transubstanciação da gratuitidade do empréstimo num dogma viu-se, no entanto, forçada a flexibilizar o seu posicionamento. Progressivamente

seguro encontrava sustentação no «valor económico e social» adstrito ao mesmo. Explicitando, partindo do pressuposto de que o comércio era uma atividade essencial para a promoção do bem comum, a legalidade dos contratos de seguro podia ser justificada pelo facto de, sem a partilha de riscos por eles facilitada, muitos negócios não poderiam ser realizados. Logo, consubstanciando-se como um instrumento fundamental para o bom funcionamento do comércio, o seguro acabava, ele próprio, por gerar um bem comum do qual toda a sociedade beneficiaria. 
assistiu-se, então, a uma evolução no sentido de nem todo interesse lucrativo cair nas malhas da usura. De entre as exceções à lei entretanto surgidas, destacámos os argumentos conexos com a incerteza futura, a razoabilidade dos ganhos (perpassada por um grau de aceitabilidade menor) e o interesse decorrente do dano emergente ou do lucro cessante. A referência aos últimos dois títulos ganhou um interesse especial para nós a partir do momento em que constatámos terem sido os mesmos de capital importância para a posterior aceitação do risco como elemento mediador do contrato. Isto é, o interesse, advindo dos mesmos passou gradualmente, a ser apreendido, não enquanto interesse lucrativo, mas, antes, como interesse compensatório, ou seja, como indemnização pelos possíveis danos decorrentes do contrato e, não mais, como recompensa pelo dinheiro anteriormente emprestado.

Como se pode deduzir do exposto, os interesses compensatórios decorriam, já não da natureza do próprio empréstimo, mas, essencialmente, das circunstâncias extrínsecas ao mesmo o que, em última instância, viria propugnar um abalo significativo nos argumentos até aí esgrimidos contra os empréstimos marítimos, na medida em que passava a poder admitir-se como legal o interesse justificado com base nos periculum sortis. Por outras palavras, a partir do momento em que, o perigo do dinheiro emprestado ser perdido, passou a ser considerado como um elemento exterior ao contrato, transmutou-se num elemento de fundamental importância para a classificação dos contratos em usurários ou não usurários. Sendo considerados do primeiro tipo, todos os contratos que produzissem lucro sem que o elemento perigo corresse do lado do mutuante e, por oposição do segundo tipo, todos aqueles onde o mutuante assumisse os perigos inerentes a esse mesmo empréstimo.

Ainda no âmbito do quadro da usura, a hipótese levantada no sentido de as proibições decorrentes da mesma terem propugnado a busca de novas estratégias por parte dos mercadores tendo em vista a partilha de riscos viria a ser comprovada. Constatando-se que, a partir dos séculos XII/XIII começam a ser utilizados novos instrumentos com o intuito de contornar os impedimentos legais da usura. Podendo-se destacar de entre os mesmos, os contratos de commenda, bem como as letras de câmbio sob a forma de «cambium siccum»e, ainda, as vendas fictícias e os contratos de revenda. 


\section{REFERÊNCIAS BIBLIOGRÁFICAS}

Böhm-Bawerk, Eugen von (1884). Capital and Interest: A Critical History of Economical Theory. London, Macmillan \& Co. (1890).

Borges, José Ferreira (1833). Diccionario Jurídico-Commercial. Porto, Typographia de Sebastião José Pereira (1856), 423 pp.

Boucher, Pierre B. (1803). Institution au Droit Maritime: Ouvrage Complet sur la Législation Maritime. Paris, Levrault Schoell, 809 pp.

Ceccarelli, Giovanni (2001). Risk Business: Theological and Canonical Thought on Insurance from the Thirteenth to the Seventeenth Century. In Journal of Medieval and Early Modern Studies, Vol. 31, n. ${ }^{\circ}$ 3. Durham, Duke University Press, pág. 607-658.

Cleirac, Estienne (1671). Les Us et Coutumes de la Mer, Vol II. Rouen, E. Viret, pág. 179-314.

Colfavru, Jean-Claude (1863). Le Droit Commercial Comparé de la France et de l'Angleterre Suivant l'ordre du Code de Commerce Français. Paris, Cosse, Marchal, 637 pp.

Coste, Adolphe (1882). Hygiène Sociale Contre le Paupérisme: le Paupérisme, L'épargne, L'association, le Crédit, L'organisation du Travail, L'impôt, L'enseignement. Paris, Germer Baillière, 532 pp.

Coulter, Gary (1999). The Church and Usury: Error, Change or Development? In URL: http://www.geocities.com/frcoulter/usury/

Daston, Lorraine (1988). Classical Probability in the Enlightenment. New Jersey, Princeton University Press (1995), 423 pp.

Denzinger, Enrique (1963). El Magisterio de la Iglesia. Manual de Los Símbolos, Definiciones y Declaraciones de la Iglesia en Materia de Fe y Costumbres. Barcelona, Editorial Herder.

Garriguet, Louis (1907). Prêt, Intérêt et Usure. Paris, Bloud, 80 pp.

Gigerenzer, Gerd; Zeno Swijtink; Theodore Porter; Lorraine Daston; John Beatty; Lorenz Krüger (1989). The Empire of Chance: How Probability Changed Science and Everyday Life. Cambridge, Cambridge University Press (1997), 340 pp.

Goff, Jacques le (1986). La Bolsa y la Vida: Economía y Religión en la Edad Media (or. La Bourse et la Vie). Barcelona, Editorial Gedisa (1996), $152 \mathrm{pp}$.

Griffiths, Gordon; Gow, Andrew (1994). Pope Eugenius IV and Jewish Money-lending in Florence: the Case of Salomone di Bonaventura during the Chancellorship of Leonardo Bruni. In Renaissance Quarterly, n. ${ }^{\circ}$ 47. New York, pág. 282-329.

Kohn, Meir Gregory (1999). Risk Instruments in the Medieval and Early Modern Economy. In URL: http://www.dartmouth.edu/ mkohn/ 
Juana, Rodrigo Muñoz de (2001). Scholastic Morality and the Birth of Economics: The Thought of Martín de Azpilcueta. In Journal of Markets \& Morality 4, n. ${ }^{\circ}$ 1. Otawa, Acton Institute/Center for Economic Personalism, pág. 14-42.

Lara, Yadira González de (2001). Institutions for Contract Enforcement and Risk-sharing: From Debt to Equity in Late Medieval Venice. In URL: http://www.eco.unibs.it/ segdse/paperseminari/th_paper.pdf

Levi, Leone (1863). International Commercial Law. Vol. II. London, V. \& R. Stevens, pág. 507-1154.

Melun, Armand de (1849). De L'intervention de la Société pour Prévenir et Soulager la Misère. Paris, Plon Frères, 68 pp.

Molloy, Charles (1769). De Jure Maritimo et Navali or a Treatise of Affaire Maritime and of Comerse. Vol. II. Londres, T. Waller, 344 $\mathrm{pp}$.

Moser, Thomas (1997). The Old Testament Anti-Usury Laws Reconsidered: The Myth of Tribal Brotherhood.

In URL: http://papers.ssrn.com/sol3/papers.cfm?abstract_id=41844

Munro, John (2003). The Late-Medieval Origins of the Modern Financial Revolution: Overcoming Impediments from Church and State. University of Toronto, Department of Economics and institute for Policy Analysis.

In URL: http://www.chass.utoronto.ca/ecipa/archive/UT-ECIPAMUNRO-01-02.pdf

Noonan, John T. (1995). Positive Law in Natural Law. In MACLEAN, George F. et all (1995). Normative Ethics and Objective Reason: Ethics at the Crossroads. Vol. 1. Washington, Council for Research in Values \& Philosophy. In URL: http://www.crvp.org/book/Series01/I-11/contents.htm

Pothier, Robert Joseph (1821). Traités des Contrats de Dépôt, de Mandat, de Nantissement, d'Assurance, de Prêt et du Jeu. In Oeuvres de Pothier. Vol. 6. Paris, Chanson, 467 pp.

Teresa, Marcos de Santa (1805). Compendio Moral Salmaticense. Vol. I. Pampelona, Imprenta de José de Rada, 662 pp.

Vermeersch, Arthur (1910). Usury. In The Catholic Encyclopedia. Vol. 15. New York, Robert Appleton Company, pág. 235-238.

White, Andrew Dickson (1898). A History of the Warfare of Science with Theology in Christendom. Vol. 2. New York, D. Appleton and Company, 394 pp. 